\title{
PROCESSES OF POPULATION AGEING AND ECONOMIC ACTIVITY OF THE ELDERLY IN THE EUROPEAN UNION BASED ON THE EXAMPLE OF POLAND AND SWEDEN ${ }^{2}$
}

\begin{abstract}
From the point of view of the labour market, the decreasing number of the productive part of society has unfavourable consequences for the socio-economic development. Population ageing is a long-term process reflected in the growing share of elderly people in the population combined with a decline in the share of people of working age in the general population. This process is an inevitable consequence of changes in the two components of natural movement - reproduction and mortality. The aim of the paper is to assess the situation of elderly people in the labour market in the face of demographic changes taking place in the EU, including Poland and Sweden. Based on empirical data, differences between Poland and Sweden in the sphere of activation of the elderly, broken down by women and men, are shown. It can be seen in the presented discussion that although both countries face similar changes in the age structure of their population, the effects of these problems, mainly from the point of view of elderly people's activity in the labour market, are different. The paper is of a factual and overview nature. It presents basic economic indicators used in assessing processes of population ageing, including the demographic burden index. Statistical analysis was carried out based on published public statistics data from the Central Statistical Office, Eurostat and SCB (Statistics Sweden).
\end{abstract}

Keywords: population ageing, lifelong learning, Europe 2020, demographic burden index.

\section{INTRODUCTION}

Population ageing is a long-term process reflected in the growing share of elderly people in the population ${ }^{3}$ combined with a decline in the share of people of working age in the general population. This process is an inevitable consequence of changes in the two com-

\footnotetext{
${ }^{1}$ Dr Elżbieta Roszko-Wójtowicz, Uniwersytet Łódzki, Wydział Ekonomiczno-Socjologiczny, 90-214 Łódź, ul. Rewolucji 1905 r. 41; e-mail: elzbieta.roszko@uni.lodz.pl.

Elżbieta Roszko-Wójtowicz, PhD, University of Łódź, Faculty of Economics and Sociology, 90-214 Łódź, ul. The 1905 Revolution 41; e-mail: elzbieta.roszko@uni.lodz.pl.

2 Treści wyrażone w artykule są opiniami autorki i nie przedstawiają stanowiska organów Narodowego Banku Polskiego.

Projekt pt. Forum Dyskusyjne - Pomiar $i$ ocena zjawisk ekonomicznych $i$ spotecznych (MASEP2017) realizowany jest z Narodowym Bankiem Polskim w ramach edukacji ekonomicznej.

3 According to the European Age Boundary, population ageing refers to an increase in the percentage of people over 60 years of age. The United Nations' proposal refers processes of ageing to the population of people $65+$.
} 
ponents of natural movement - reproduction and mortality ${ }^{4}$. On the one hand, a decline in the fertility rate, and on the other hand, extended average life expectancy lead to changes in the age structure of the population. Population ageing is also a direct consequence of migration balance ${ }^{5}$. The share of people aged 65 and over is increasing in every Member State of the European Union. At the same time, the share of people under the age of 20 in the population is decreasing. Population ageing in the demographic sense is a dynamic process, understood as an increase in the share of elderly people in society ${ }^{6}$. Therefore, it refers to significant changes in the age structure of the population. Demographic ageing, on the other hand, is a static term describing the existence of a state in which the growing share of the oldest population, i.e. above 65 , is accompanied by a falling share of young people in the population. Thus, the process of population ageing can be shown by comparing the share of elderly people in the same group at different times, and demographic ageing by comparing the percentage of elderly people in different groups at the same time ${ }^{7}$. From the point of view of the labour market, the decreasing number of the productive part of society has unfavourable consequences for the socio-economic development. The progressive ageing of society is a great challenge for gross domestic product and its intergenerational redistribution. An increase in the percentage of elderly people in the country's population will lead to an increase in pension and social benefits as well as a growing burden on working age persons. The effects of this phenomenon will be felt directly by pension systems due to a significant increase in the group of beneficiaries and a reduction of the group of people creating GDP. This causes a problem in the form of a huge burden for public finances and results in the need to reach a consensus on the distribution of real incomes in intergenerational relations. For many elderly people, receiving a pension proves to be more attractive than continuing to work, especially if their pay is low $^{8}$.

Population ageing results directly from the fact that people live longer, and successive generations have a chance for a longer life together. This is a huge civilisational success. On the other hand, without undertaking the necessary reforms in the field of social policy, especially taking preventive measures, adverse and undesirable social phenomena may occur, such as poverty, severe loneliness, poor health or social exclusion. In many spheres of life, seniors are exposed to the risk of social marginalisation ${ }^{9}$. An important issue is also a large increase in the demand for social and healthcare services. In attempts to activate elderly people, health care should focus on prevention, as the OECD points out. Better preventive health care can reduce the occurrence of diseases that are a result of lifestyle as well as occupational diseases, and as a consequence may prolong the period of professional activity ${ }^{10}$. The population ageing process is also considered in negative terms due to reduced

\footnotetext{
${ }^{4}$ P. Szukalski, Proces starzenia się ludności. Przyczyny, etapy, konsekwencje [in:] Geriatria z elementami gerontologii ogólnej. Podręcznik dla lekarzy i studentów, ed. T. Grodzicki, J. Kocemba, A. Skalska, Gdańsk 2006, p. 13-14. http://dspace.uni.lodz.pl/xmlui/bitstream/handle/11089/ 14269/geriatria.pdf?sequence=1\&isAllowed=y (accessed: 01.10.2017).

5 E. Rosset, Proces starzenia się ludności. Studium demograficzne, Warszawa 1959.

6 Z. Wiśniewski, Determinanty aktywności zawodowej ludzi starszych, Toruń 2009, p. 75.

7 Ibidem, p. 75.

8 E. Kwiatkowski, B. Liberda, Determinanty rozwoju Polski. Rynek pracy i demografia, Warszawa 2015, p. 275.

9 R.J. Kijak, Z. Szarota, Starość. Między diagnoza a działaniem, Warszawa 2013, p. 23-33.

${ }^{10}$ OECD, MPiPS, Starzenie się i polityka zatrudnienia. Polska 2015. Lepsza praca wraz z wiekiem, Warszawa 2015, p. 25-26.
} 
mobility and flexibility of labour force resources or a decline in competitiveness and innovativeness of the economy. From the point of view of enterprises' competitiveness, competences are the decisive factor in terms of the quality of human resources. In the face of changes taking place as a result of globalisation and computerisation, qualifications such as foreign languages or computer skills are important for contemporary employers. As a rule, elderly people have the biggest problems with these skills. Promotional activities that encourage elderly people to pursue continuing education and raising qualifications are key in this respect ${ }^{11}$. In the light of these issues, there are challenges facing the European Union Member States, including the need to minimise negative effects of population ageing and shrinking labour market resources.

The aim of the paper is to assess the situation of elderly people in the labour market based on public statistics in the face of demographic changes taking place in the European Union, including Poland and Sweden. The paper provides a comparative analysis of processes of population ageing in Poland and Sweden from the point of view of selected age and gender groups. Based on empirical data, the differences between Poland and Sweden in the sphere of activation of elderly people are shown. In the course of the discussion, it was shown that although both countries face similar changes in the age structure of the population, the effects of these problems, mainly from the point of view of elderly people's activity in the labour market, are different. In the research conducted for Poland, the choice of Sweden as a comparative country serves to show examples of actions effectively preparing society for population ageing as well as to indicate possible methods conducive to the activation of elderly people in the labour market. Among the EU countries, the Swedish labour market is notable for its very good situation. Elderly labour market participants in Sweden are characterised by high professional activity, high employment rate, relatively low unemployment rate and low long-term unemployment rate ${ }^{12}$. The Swedish government, in order to counteract premature professional deactivation of people at the pre-old age, changed the pension and disability system in 1999 and is constantly taking steps to increase the economic activity of elderly people. Elderly employees are provided with flexible working hours and the opportunity to combine work and retirement. Specialised courses and training for this group of employees are also organised. This allows elderly employees to upgrade their qualifications, at the same time preventing their skills from becoming outdated. The Swedish government is also investing in improving health services and care for people aged $65+$, assuming that a healthy child is a healthy senior in a few dozen years' time. The approach applied to the individual's health takes into account the human life cycle. And Swedish companies, aware of the demographic situation, and especially of the ageing of the labour force, have long applied age management as one of the elements of the system to counteract early professional deactivation of people over 50 years of age.

The paper has a factual and overview nature. It discusses basic economic indicators used in assessing processes of population ageing, including the demographic burden factor. Statistical analysis was carried out based on published public statistics from databases of the Central Statistical Office of Poland, Eurostat and SCB (Statistics Sweden).

${ }^{11}$ I. Kołodziejczyk-Olczak, Zarządzanie pracownikami w dojrzatym wieku. Wyzwania i problemy, Wydawnictwo Uniwersytetu Łódzkiego, Łódź 2014, p. 91.

12 Z. Szweda-Lewandowska, Raport krajowy - Szwecja. Rozdział VIII, Raport krajowy - Szwecja [in:] Rozwiazania sprzyjające aktywnemu starzeniu się w wybranych krajach Unii Europejskiej. final report, ed. E. Kryńska, P. Szukalski, Łódź 2013, p. 117-126. 


\section{ECONOMIC INDICATORS IN THE ASSESSMENT OF PROCESSES OF POPULATION AGEING}

The development of economic activity, employment and unemployment, is usually the subject of analysis of the labour market not only because of the situation in it but also due to its importance for the course of demographic processes. Economic activity is a concept that is in common use, yet it is understood in various ways. In Poland, since the beginning of the 1990s, the term economically active population has been used, which means the population constituting the workforce comprising employed and unemployed people. Earlier, in the centrally planned economy, the term professionally active population was used, corresponding to the current category of the employed. The analysis of the economic activity of the population can be made on the basis of the economic activity rate which expresses the share of economically active people in the total population aged 15 (or 18) and more, which can be presented in the form of the following formula ${ }^{13}$ :

$$
W_{a z}=\frac{L_{a z}}{L_{x}} * C
$$

where: $L_{a z}$ - number of economically active people, $L_{x}$ - number of people aged 15 (or 18 ) and more, $C$ - fixed number (generally 100).

In the assessment of the socio-occupational structure of the population, the main role is played by indicators that express the share of economically active persons in the total population ${ }^{14}$. However, other measures, in particular the employment rate and unemployment rate, are also used to determine certain trends in the labour market. It is also possible to show the scale of unemployment and employment in absolute terms, which plays a significant role, in particular from the point of view of conducting national analyses. In the light of international comparisons, the presentation of the studied phenomenon in relative terms is much more convenient. The employment rate, which is one of the basic measures assessing the situation in the labour market, expresses the percentage share of the employed (total or for a given group) in the economically active population (total or for a given group). It can be calculated using the following formula ${ }^{15}$ :

$$
W_{z}=\frac{L_{p}}{L_{x}} * 100 \%
$$

where: $L_{p}$ - number of the employed, $L_{x}$ - number of people aged 15 (or 18 ) and more.

In the case of measuring the phenomenon of unemployment, the basic measure of its intensity is the so-called unemployment rate which determines what percentage of economically active persons (total or for a given group) is unemployed (total or for a given group). This indicator can be expressed by the following formula:

$$
S_{b}=\frac{L_{b}}{L_{a z}} * 100 \%
$$

where: $L_{b}$ - number of the unemployed, $L_{a z}$ - number of economically active persons.

\footnotetext{
13 J.Z. Holzer, Demografia, wydanie VI zmienione, Warszawa 2003, p. 154.

${ }^{14}$ Ibidem, p. 147.

${ }^{15}$ GUS, Zasady metodyczne statystyki rynku pracy i wynagrodzeń, Warszawa 2008, p. 21.
} 
In the face of progressing demographic changes, one of the factors useful for the assessment of the age structure of the population, and also helpful in the analysis of the occupational structure of the population and the labour market, is the demographic burden factor ${ }^{16}$, otherwise referred to as the economic burden indicator. The ratio of elderly people to young people, which this coefficient explains, plays a significant role in the labour market, as it is related to labour supply forecasts as well as issues associated with covering pensions with contributions of working age people. Demographic burden calculation was made using the traditional (classical) demographic burden measure ${ }^{17}$. In practice, demographic burden factors are used as indicators of supporting young people (e.g.: aged 0-14, aged $0-19^{18}$ ) or elderly people (aged 65+) by the employed population (conventionally aged 15-64) ${ }^{19}$. In special cases, it may the burden of the working age population by both groups at the same time, which can be shown in the form of the following formulas ${ }^{20}$ :

$$
\begin{aligned}
& W_{\text {od } 0}=\frac{L_{0-19}+L_{65+}}{L_{20-64}} * 100 \\
& W_{\text {od } 0}=\frac{L_{0-19}}{L_{20-64}} * 100 \\
& W_{\text {od } 0}=\frac{L_{65+}}{L_{20-64}} * 100
\end{aligned}
$$

where: $L_{0-19}-$ number of people aged $0-19, L_{65+}-$ number of people aged $65+, L_{20-64}-$ number of economically active people (aged 20-64).

The above-presented indicators provide an answer to the question of how many nonworking age people (total or in terms of children and adolescents or elderly people) there are per 100 working age people ${ }^{21}$.

To prepare the socio-demographic description, the fertility rate was also used in the next part of the study. The rate determines the average number of children that would be born per woman if she were to live to the end of her child bearing years and give birth to children in alignment with the prevailing age-specific fertility rates, which can be expressed by the following formula:

16 J. Kurkiewicz (ed.), Procesy demograficzne i metody ich analizy, Kraków 2010.

${ }^{17}$ In addition to the classical measure of demographic burden, there is also a potential measure of demographic burden using the concept of potential demographics.

18 Demographic ageing is affected not only by the size of the elderly population but also by the size of the youngest group - aged 0-14, 0-19, and the index value for the 9-14 age group is also calculated.

${ }^{19}$ Urząd Statystyczny w Zielonej Górze, Społeczno-gospodarcze uwarunkowania i konsekwencje wydłużania życia ludzkiego w Europie Środkowej w czasach nowożytnych. Materiały z Zielonogórskich Spotkań z Demografią, Zielona Góra 2012, p. 12, https://stat.gov.pl/cps/rde/xbcr/gus/ POZ_folder_konf_prezentacja.pdf (accessed: 19.09.2017).

${ }^{20} \mathrm{OECD}, \mathrm{MIiR}$, Analiza wskaźnika zmian demograficznych w wybranych regionach $w$ Polski, MIiR, OECD - Local Economic and Employment Development (LEED), Warszawa 2013, p. 10, https://www.ewaluacja.gov.pl/media/42330/Raport_analiza_wskaznika_zmian_demograficznych. pdf (accessed: 12.08.2017).

${ }^{21}$ F. Stokowski, Demografia, Warszawa 2015, p. 55. 


$$
W_{d z}=\sum_{x=15}^{49} W_{p t(x)}
$$

where: $W_{p t(x)}$ - fertility rate for individual years of woman's child-bearing age per one woman $^{22}$.

\section{CHARACTERISTICS OF DATA SOURCES - METHODOLOGICAL REMARKS}

From the point of view of conducting statistical analyses, the population by age is presented according to years, five-year periods and functional age groups. These groups include, among others, economic age groups and biological age groups. Within the framework of the economic age groups, the division encompasses ${ }^{23}$ :

- pre-working age - men and women aged 0-17,

- working age - men aged 18-64 an women aged 18-59:

- mobile age (men and women aged 18-44),

- immobile age (men aged 45-64 and women aged 45-59),

- post-working age - men aged $65+$ and women aged $60+$.

The non-working age population comprises the pre-working age population and the post-working age population. The working-age population is the population with the capacity to work.

In addition, biological age groups are distinguished, including the three basic most commonly used groups:

- 0-14 years - children (demographic youth);

- 15-64 years - adults without elderly people;

- 65+ - elderly people (demographic ageing).

Analyses taking into account the above-described divisions were carried out in this paper. The assessment of demographic changes in the EU, including Poland and Sweden, was conducted based on data from databases of the Central Statistical Office, Eurostat and SCB (Statistics Sweden). For the purpose of developing the empirical part of the paper, the Demografia database and the Strateg system were also used. Data on the population structure by sex and selected age groups were used as the source material. The demographic situation of the European Union, including Poland and Sweden, was discussed on the basis of the most up-to-date data available in the above-mentioned databases - i.e. the year 2016. Population forecasts until 2080 are presented based on the Eurostat database - Baseline projections [proj_15npms]. On the basis of the available source data, the demographic burden for the EU, Poland and Sweden was assessed in the following decades: from 2000 up to 2080 . By 2016, the reference point is real data and from 2020 onwards predicted data.

22 J.Z. Holzer, Demografia..., p. 253; M. Wróbel, Modele dzietności względem zmiennych rynku pracy w miastach 100-tysięcznych i większych w pierwszej dekadzie XXI wieku [in:] Polityka rodzinna w Polsce z perspektywy wybranych aspektów polityki spotecznej i ekonomii Doświadczenia innych państw europejskich, ed. A. Kubów, J. Szczepaniak-Sienniak, "Prace Naukowe Uniwersytetu Ekonomicznego we Wrocławiu" 2014, nr 364, p. 97, http://www.dbc.wroc.pl/Content/27028/ Wrobel_Modele_dzietnosci_wzgledem_zmiennych_rynku.pdf.

${ }^{23}$ GUS, Podstawowe informacje o rozwoju demograficznym Polski do 2014 roku, Information Note, Warszawa 2015, p. 15-16. 


\section{Demographic determinants in Poland and Sweden compared to the European Union}

In the light of forecasts and statistical analyses, it can be seen that processes of population ageing are occurring in all European countries. In assessing the intensity of this phenomenon, the population age pyramid, which is constructed for one year, is used. It is a graphic image captured in the form of a horizontal bar chart showing the share of the population of a given age group in the total population in a given geographical area (city, state, continent, world) ${ }^{24}$. The vertical axis of the chart (the y-axis) is used to present the population age according to usually five-year age increments marked on it. The horizontal axis (the x-axis), on the other hand, shows the share of particular age groups expressed as a percentage ${ }^{25}$. The chart usually presents data for both sexes separately, hence the ordinate axis is in the middle of the chart. The shape of the pyramid shows the image of the society according to the separate age groups and allows one to read future trends in population changes. The age pyramid is helpful in (1) assessing the current state of the population, (2) assessing past events and behaviours, and (3) determining the directions of future changes. In the face of population ageing processes, the shape of the age pyramid changes. Young societies with a large number of births and short life expectancy have the shape of a pyramid with a broad base tapering upwards (the shape of an isosceles triangle). In old societies (demographic ageing) in which the number of births is small and average life expectancy is very high, the pyramid has a clearly narrow base (spindle-shaped). At present, in the EU countries, the population age pyramid takes the shape of a spindle, the base of the chart becomes narrower, in addition, more and more convexities around the apex are observed. The increase in the relative share of elderly people can be explained by increasing life expectancy. This change is often referred to as 'ageing' at the top of the age pyramid. On the other hand, a consistently low fertility rate with fewer births, which leads to a decline in the proportion of young people in the entire population, contributes to population ageing. This process is referred to as 'ageing' at the bottom of the population pyramid. By 2080, slightly narrowing in the middle (aged 45-54) and much more narrowing near the base, the pyramid will adopt a more compact shape. Another aspect of population ageing is the progressive ageing of the elderly population itself. The share of the oldest $(75+)$ persons in the $65+$ group is growing at a much higher pace than the share of any other group in any age segment of the EU population ${ }^{26}$.

It is predicted that in the period 2016-2080, there will be over 38 million population growth in the EU countries in the 60+ age group. Over the past 15 years, the percentage of people over 65 has increased among the population of the European Union by $4.72 \%$. According to Eurostat data, the population of the EU has increased by $4.83 \%$ since 2000 , but by 2080 it will grow by only $2.5 \%$. It is worth noting that the demographic growth expressed in the growing total number of European citizens, and stabilisation of this value in recent years, has occurred as a result of the inflow of inhabitants from other continents. In the distant future, however, we should expect depopulation processes of the European Union's population due to the global regularity observed in changes in the age structure of ageing

24 J. Kurkiewicz (ed.), Procesy demograficzne i metody ich analizy, Kraków 2010, p. 105-108.

${ }^{25}$ Values on the horizontal axis can be expressed as absolute numbers, while in the case of comparative analyses it is better to use relative values.

${ }^{26}$ Eurostat, Population structure and ageing, Statistics Explained, 2017, p. 8, http://ec.europa.eu/ eurostat/statistics-explained/index.php/Population_structure_and_ageing (accessed: 18.08.2017). 
societies. On a global scale, it is Western civilisation, and in particular Europe, which is getting older at the fastest pace. It is manifested in the growing percentage of elderly people (aged 65+) in the total population of this area and the decreasing share of children and youth (aged 0-19) ${ }^{27}$.
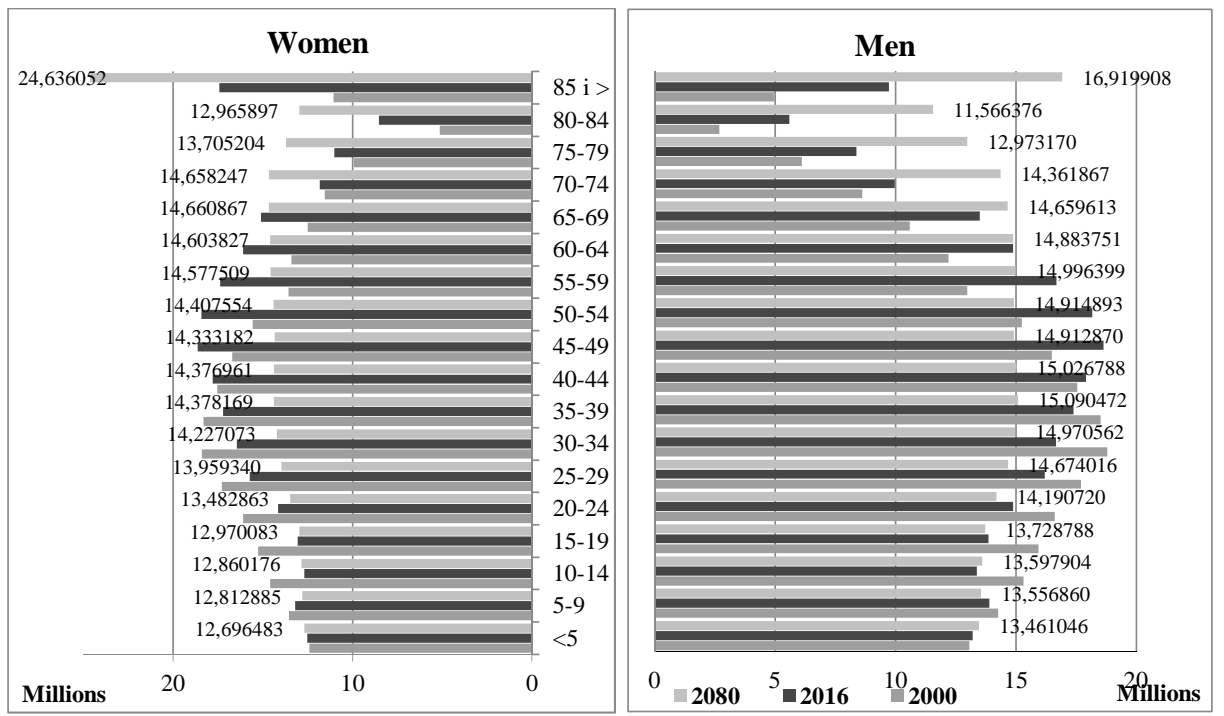

Figure 1. Structure of the EU population in the years 2000-2080 by age groups (in millions of people) Source: own study based on Eurostat data: http://epp.eurostat.ec.europa.eu/portal/page/portal/population/data/database [demo_pjan], [proj_15npms].

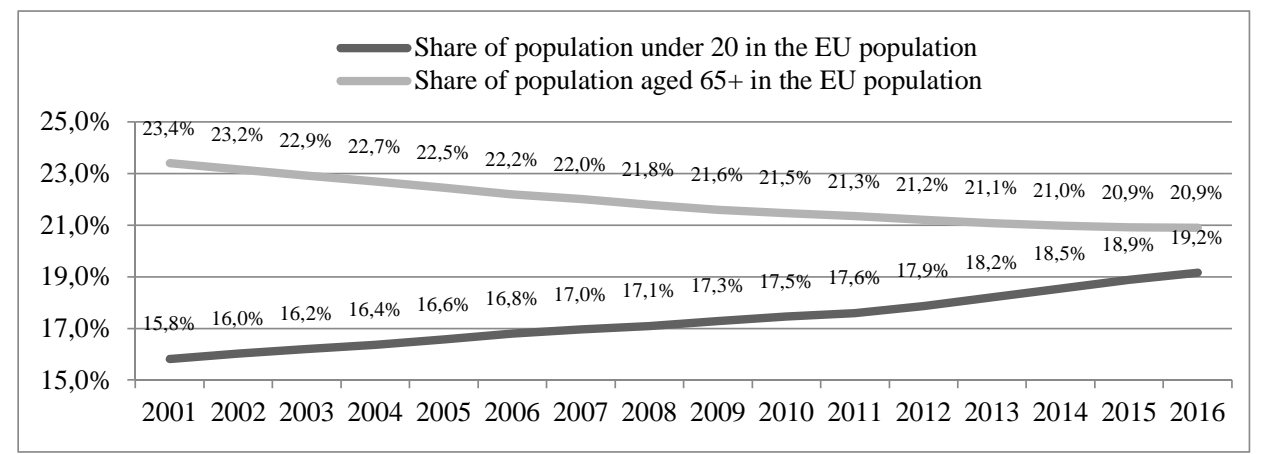

Figure 2. Share of population aged $65+$ and under 20 in the EU-28 population in the years 2001-2016 (\%)

Source: own study based on Eurostat data: http://epp.eurostat.ec.europa.eu/portal/page/portal/population/data/database [demo_pjangroup].

${ }^{27}$ E. Kwiatkowski, B. Liberda, Determinanty rozwoju Polski. Rynek pracy i demografia, Warszawa 2015, p. 266-267. 
In 2016, the percentage of people $65+$ was $21.9 \%$. At the same time, it was higher than the percentage of children and youth by 1 percentage point, and it is expected that by 2080 the share of elderly people will increase and exceed the percentage of children and young people by 8.7 percentage points. Therefore, if the European Union countries do not take any actions to alleviate these disproportions, the demographic trends in Europe, consistent with the forecasts, will threaten its sustainable development, and in particular the relationship between people working and receiving pensions ${ }^{28}$.

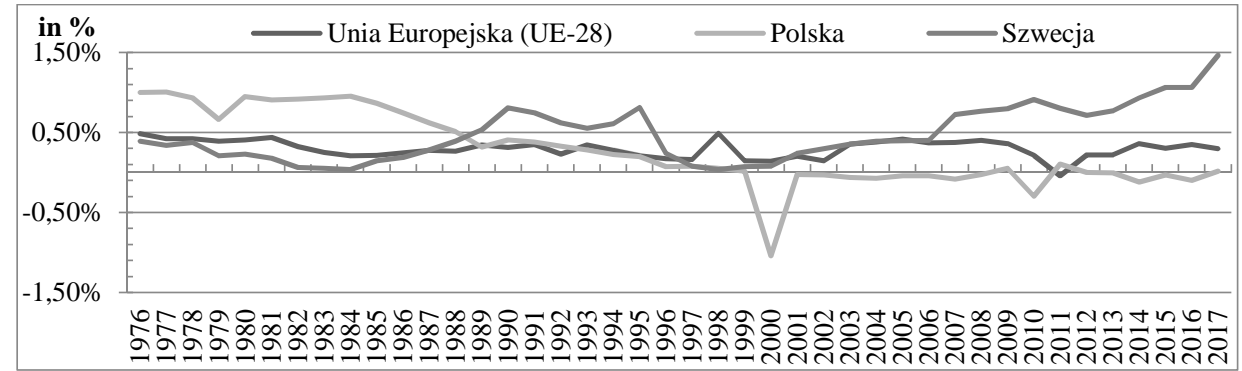

Figure 3. Dynamics of the population growth in the EU, Poland and Sweden in the years 1975-2017 (\%)

Source: own study based on Eurostat data: http://epp.eurostat.ec.europa.eu/portal/page/portal/population/data/database [demo_gind].

The conducted comparative analysis shows that a slowdown in demographic growth has been observed in the last 15 years in Poland and that the population has been systematically decreasing. The observed trend in Poland is completely opposite to that occurring in Sweden. In both countries, however, significant changes in the age structure are visible. The number of elderly people is increasing both in Poland and in Sweden. The largest increase in the number of people is observed in the oldest age group which includes people over 80 years of age. In the case of Sweden, since 2000, the share of people 64+ in the total population has significantly increased. The number of people aged $65+$ living in Sweden increased by nearly $24.0 \%$ in 2016 compared to 2000 . At the same time, the share of people over 64 in the total population increased significantly over the analysed period. In 2000, the percentage of people $65+$ was less than $20.0 \%$, while in $2016-22.2 \%$. By 2080 , it is expected that it will increase by about 3.5 percentage points and the number of people over 64 years of age will exceed 3.7 million. It is estimated that at the end of the forecast period, elderly people will account for as much as $25.8 \%$ of the population.

According to CSO data, the Polish population at the end of 2016 was 38.4 million, of which over 6 million were people aged $65+$, which is $16.4 \%$ of the population. However, according to Eurostat forecasts, by 2080 this percentage will almost double, to over $32.8 \%$, which means that almost every third inhabitant of Poland will be in the post-working age. For comparison, the percentage of children and young people (aged 0-19) will be less than $18 \%$ according to the above-mentioned forecasts. This negative trend is already observed, since, as Eurostat data show, in the last 16 years, this percentage decreased by more than 8 percentage points, from $28.5 \%$ in 2000 to $20.2 \%$ in 2016. In Sweden, however, the predicted

${ }^{28}$ Ibidem, p. 271-271. 
share of children and youth in the total population will increase by 0.22 percentage points, from 22.7 to $22.9 \%$. By 2080, the number of Swedish inhabitants will gradually increase from year to year. At the end of the forecast period, it is expected to exceed 13 million. Such a large increase is attributed mainly to the immigration inflow, as the population born abroad constitutes an increasing part of the population of Sweden.

It is worth noting that immigration plays a large role in the reflection on the processes of reproduction of the population of Europe, as countries with a relatively high fertility rate are often characterised by the intensification of immigration processes, i.e. a high percentage of immigrants and their descendants in the population ${ }^{29}$. In relation to Sweden, its population in 2060 will be more numerous by almost 3.2 million people according to SCB (Statistics Sweden) forecasts. This number constitutes almost 1/3 of the present population, and migrations have a significant impact on its growth. In Sweden, since 1930 (except for a few years) there has been an immigration surplus, i.e. an inflow is greater than the outflow of population. In 2015, the percentage of the Swedish population comprised of people born in another country was $17 \%$. For comparison, in Poland in 2015 the percentage of foreigners in the population amounted to only $1.6 \%{ }^{30}$. In the case of Sweden, this percentage has doubled since 1970, and in the next years it is forecast to increase, reaching $22 \%$ in 2060 (SCB 2016; SCB 2015). When looking at the structure of the population by age and the changes that will have occurred by 2080 , it can be concluded that the phenomenon of population ageing will not be as dynamic in Sweden as in Poland. In view of the anti-immigration policy propagated almost all over Europe, the correction of the demographic situation of the country by an influx of foreigners will significantly lose its importance in the next decades. However, countries that so far, like Sweden, have been characterised by a large openness and have willingly accepted foreigners will continue to experience positive consequences in the following years of resettlement of foreigners.

The increase in the number of elderly people is a consequence of also other processes, i.e. extended average life expectancy and a reduction in the fertility rate as a result of which fertility often remains at a level below the simple replacement of generations. The first of the trends, considered positive, is associated with an increase in the standard of living, advancement in the field of medicine and a comprehensively developed area of social security $^{31}$. Replacement of an increasingly smaller population and negative population growth are explained by:

- a growing number of divorces, marriages at a later age, an increase in the role of cohabitation and LAT-type (Living Apart Together) relationships;

- changes in the fertility pattern, i.e. delayed parenthood;

- the spread of contraceptive methods;

- lifestyle changes ${ }^{32}$.

${ }^{29}$ M. Krywult-Albańska, M. Wałaszek, Procesy reprodukcji ludności w Europie [in:] Wspótczesne problemy demograficzne $w$ dobie globalizacji: aspekty pozytywne i negatywne, „Studia Ekonomiczne. Zeszyty Naukowe Wydziałowe Uniwersytetu Ekonomicznego w Katowicach" 2011, nr 95, ed. M. Balcerowicz-Szkutnik, Katowice, p. 152.

30 According to published data, in 2015 only 611,855 foreigners lived in Poland. For detailed information see Eurostat [migr_pop3ctb].

${ }^{31}$ L. Frąckiewicz, Polska a Europa. Procesy demograficzne u progu XXI wieku. Proces starzenia się ludności Polski i jego społeczne konsekwencje, Katowice 2002, p. 28.

${ }^{32}$ F. Stokowski, Demografia, Warszawa 2015, p. 33-34. 

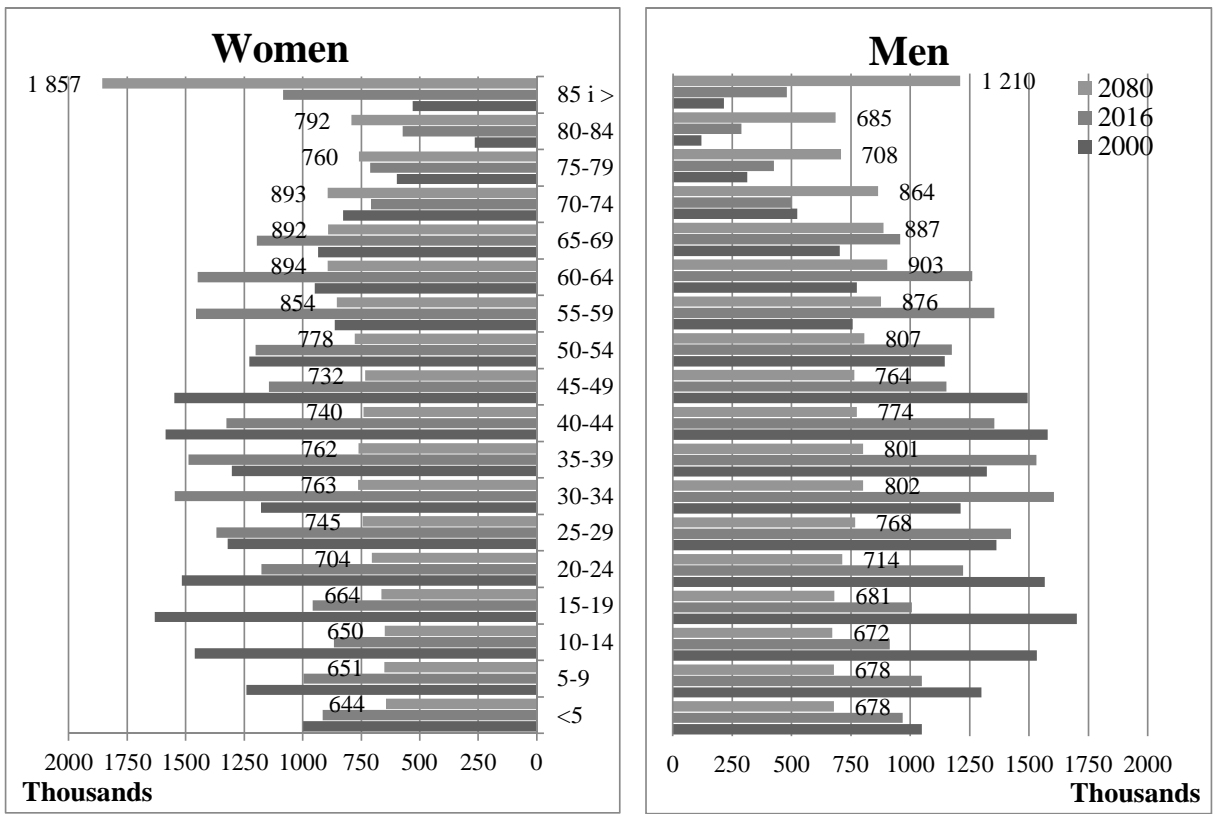

Figure 4a. Age structure of the population of Poland in the years 2000-2080 (in thousands)

Source: own study based on Eurostat data: http://epp.eurostat.ec.europa.eu/portal/page/portal/population/data/database [demo_pjan], [proj_15npms].
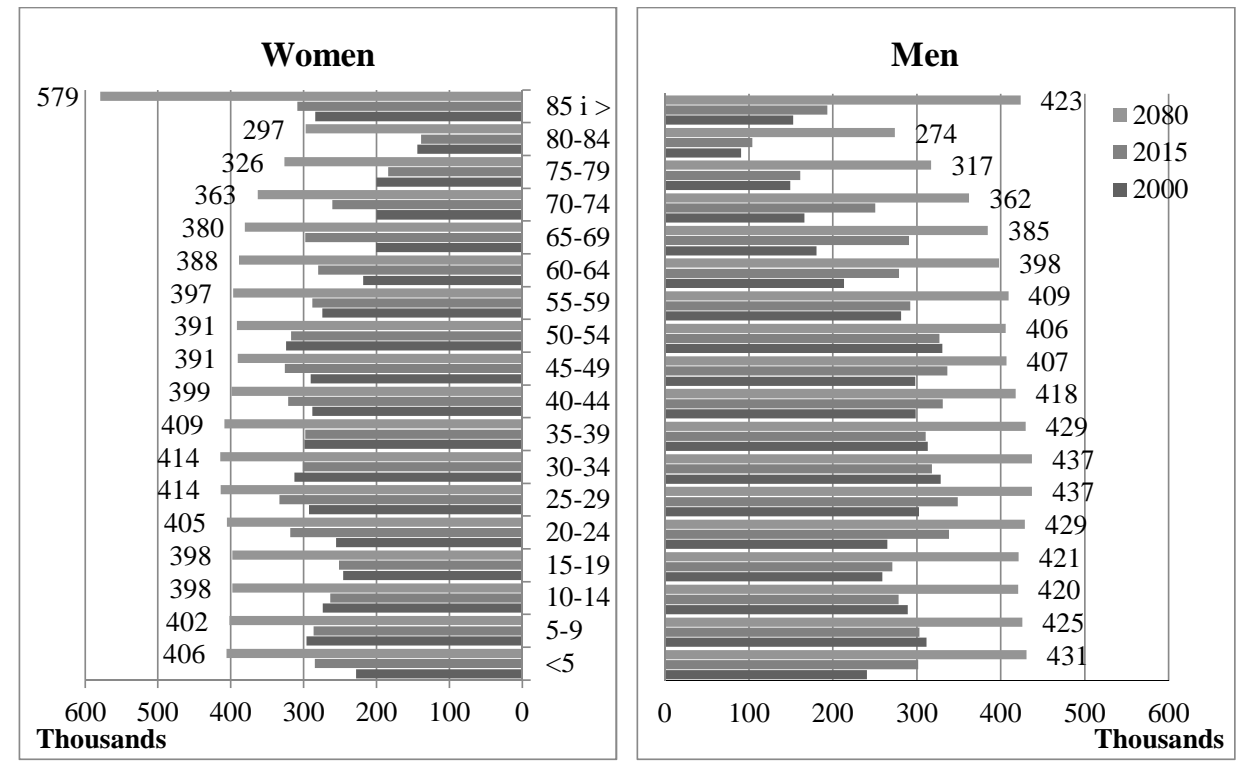

Figure 4b. Age structure of the population of Sweden in the years 2000-2080 (in thousands)

Source: own study based on Eurostat data: http://epp.eurostat.ec.europa.eu/portal/page/portal/population/data/database [demo_pjan], [proj_15npms]. 


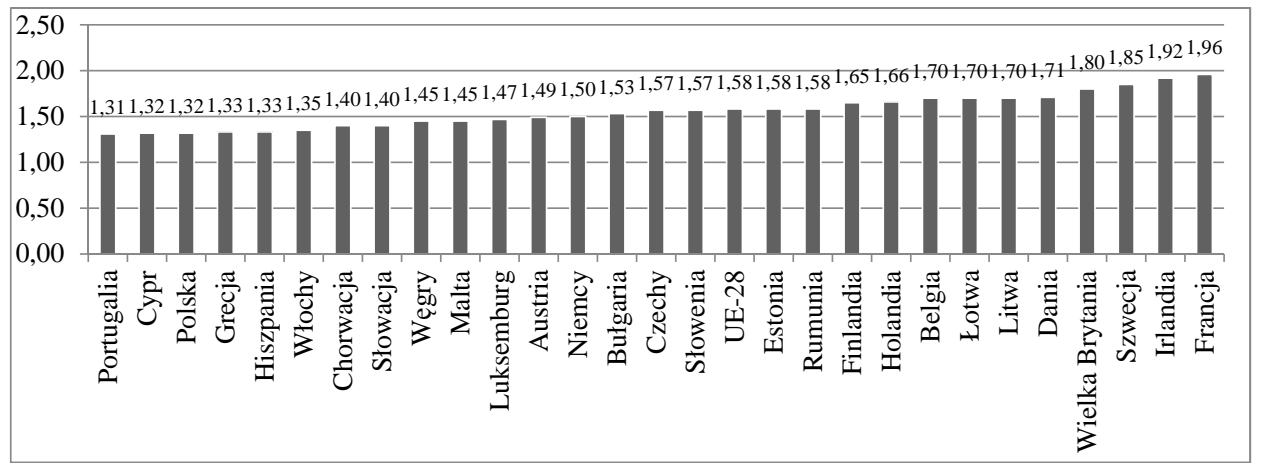

Figure 5. Fertility rate for the EU Member States in 2015 (number of children per one woman)

Source: own study based on Eurostat data: http://epp.eurostat.ec.europa.eu/portal/page/portal/population/data/database [demo_find].

The fertility rate is the most common way to measure fertility. There are several explanations for changes in fertility over time, including changes in the participation of women in the labour market and the use of educational offer. External social factors, such as the character and shape of the family policy implemented by the state, are also important for the propensity for having children. The fertility rate in Sweden is one of the highest in Europe. In 2015, it amounted to 1.85 children per woman. Only France (1.96 children per woman) and Ireland (1.92 children per woman) in the period considered were characterised by higher fertility rates than in Sweden. However, the fertility of Europeans is characterised by a worrying downward trend, i.e. in all the EU countries 40 years ago the fertility rate exceeded 2 or was only slightly lower, thus ensuring the achievement of the simple replacement of generations. Poland in comparison with Europe belongs to the group of countries with very low fertility, occupying the third position from the end with the rate of just 1.32 children per woman. In the EU, the average fertility rate amounted to 1.56 children per woman in 2015, and since 1970 it has dropped by over 33 percentage points.

The birth rate in Sweden has fluctuated compared to many other countries. In 1990, a relatively large number of children were born, i.e. 124,000 (the value of the fertility rate equal to 2.13). However, 9 years later, in 1999, only 88,000 babies were born. Since 2000, the birth rate has risen again, which can be seen in the number of births, e.g.: in 2015, almost 115,000 births were recorded. In view of the above, it is recognised that Sweden, as per European standards, is a country with a relatively high fertility rate. Demographic forecasts for Sweden assume an increase in this rate in subsequent years. It is expected that in 2021 the fertility rate will amount to 1.95 children per woman in this country, and this increase in the fertility rate in the coming years is seen as a result of a high level of immigration. The number of immigrants born in countries outside of Europe with a medium level of development is a group that historically has had a relatively high birth rate, especially in the first years after immigration. This means that according to forecasts, the number of births will be increasing by at least the year 2023 due to the large immigration in recent years, although not only, as people born around 1990, i.e. in the baby boomer years, will begin to enter the child-bearing age. The migration is largely a result of political instability in various parts of 
the world. Changes in the level of migration are difficult to predict, as they can occur suddenly and rapidly. In addition, immigration is shaped by armed conflicts and the general socio-economic situation in the world. The influence of the civil war in Syria on the migration to Sweden is assumed ${ }^{33}$. Sweden's immigration policy also plays a role in such a large inflow of immigrants and refugees from other parts of the world.

Poland, on the other hand, is one of the least fertile countries in Europe. The number of births has been systematically declining for twenty years and in the forecast period (Figure 4a) the population of women at child bearing age (15-49 years) will shrink by 2080 by almost 3.9 million, which is only slightly above $43 \%$ of their present number. In 2016, their share in the total population of the country amounted to less than $23.7 \%$, and it is predicted that the percentage of women aged 15-49 at the end of the forecast period will be only $17.6 \%$. These unfavourable predicted changes will bring a lasting decline in births by 2080 , as a consequence having a negative impact on the structure of the group of children and young people. At the same time, it is worth noting that in Poland immigration will not become a component of demographic growth as much as in Sweden.

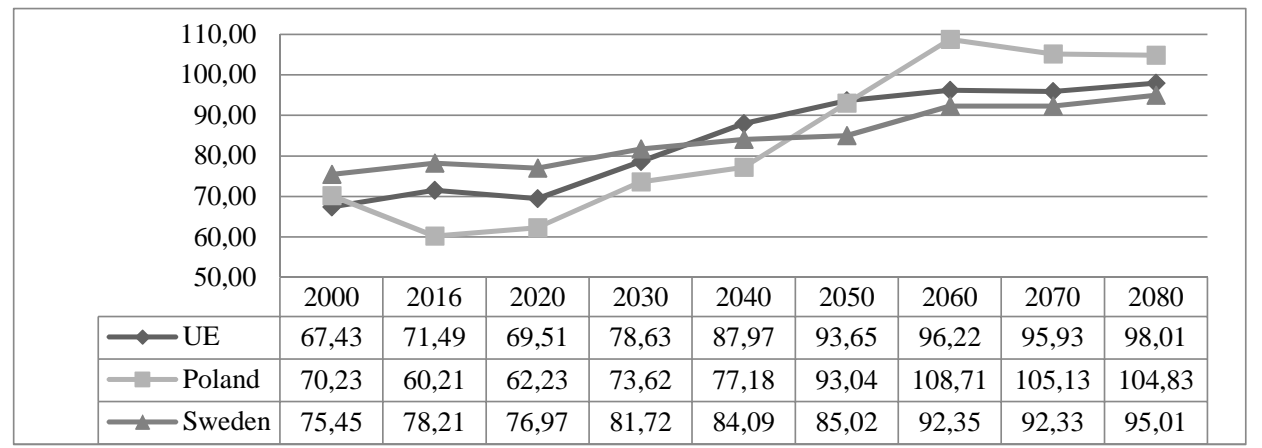

Figure 6. Demographic burden indicator in the EU, Poland and Sweden in the years 2000-2080

* for 2000 and 2016 real data, for the years 2020-2080 predicted data

Source: own study based on Eurostat data: http://epp.eurostat.ec.europa.eu/portal/page/portal/population/data/database [demo_pjan], [proj_15npms].

It is true that Poland is perceived as a demographically young country compared to the EU average; however, when analysing the demographic burden indicator, the image of Poland as a young country is not so evident. This indicator shows the number of people at non-working age per 100 persons of working age, and it is calculated as the quotient of the first of these groups in relation to the other. In addition, in the light of forecasts, it can be assumed that Poles will become one of the oldest nations in Europe due to the rapid pace of unfavourable changes. Before conducting the analysis of the demographic burden indicator,

${ }^{33}$ SCB, Sveriges framtida befolkning 2016-2060, Statistiska Meddelanden, SCB, Stockholm 2016, http://www.scb.se/Statistik/BE/BE0401/2016I60/BE0401_2016I60_SM_BE18SM1601.pdf, (accessed: 18.06.2017); SCB, The future population of Sweden 2015-2060, Demographic reports, SCB, Stockholm 2015, https://www.scb.se/Statistik/_Publikationer/BE0401_2015I60_BR_ BE51BR1502.pdf, (accessed: 18.06.2017). 
it is worth noting that this indicator includes the indicator for children and young people and for post-working age people as well as the overall burden indicator including both groups $^{34}$. The value of the demographic burden indicator, just as the percentage of elderly people, will also grow throughout Europe and probably, in 2080, on average, there will be as many as 98 people at non-working age per 100 working age persons, while in 2016 for every 100 working persons there were 66.12 persons at non-working age (0-19 years and $65+)$. In Poland and Sweden as well as in other EU countries, the expected increase in the demographic burden indicators is a result of a decrease in the burden of children and youth and the growing burden related to the population aged 65+. Due to the fact that in Poland in the years 2000-2015 the dynamics of the population burden increase related to the postworking age group was greater than the dynamics of the decrease in the burden of children and youth, there was a decrease in the overall demographic burden factor. In the case of Sweden, there has been a lack of ageing labour resources in recent years, as the share of people aged 45-64 in the group of people of working age (20-64) increased very slightly from $43 \%$ to $43.2 \%$ in the studied 16 years. For comparison, in Poland this percentage increased by as much as 3.6 percentage points, from $38.6 \%$ to $42.1 \%$. At the same time, it is worth noting that the increase for Poland is smaller than for the European Union, in which the percentage of the 45-64 age group in the working age group increased from $39.65 \%$ to $45.8 \%$, i.e. by more than 6 percentage points. It can be noted that in Poland, as well as in other European countries, the importance of elderly people in terms of potential and real labour resources is very high.

\section{THE ELDERLY AND THE LABOUR MARKET}

Due to the dynamisation of the phenomenon of population ageing and the decreasing share of the working age part of society, unfavourable effects on the functioning of the labour market should be expected. Currently, the potential labour resources of the elderly generation are used in Poland to a much lesser degree than in Sweden. At the same time, Poland, with the employment rate which has been steadily increasing since the accession to the EU and which is at a relatively high level in the 20-64 age group - 69.3\% in 2016 (compared to the EU average - 71.1\%), is one of the countries with the lowest employment rate for people at the near retirement age. For the 60-64 age group, the average rate for women and men in 2016 was only $30.7 \%$, while in Sweden it was at the level of $67.7 \%$, which is much higher than the EU average (40.9\%). When analysing the employment rate of persons of immobile non-working age, one can observe a certain regularity. This rate is higher for men than for women. This situation may result from (1) lower retirement age for women than men in many EU countries, (2) biological, social or economic conditions, e.g.: motherhood, upbringing of children, and (3) stereotypes prevailing in a given culture.

In 2016, the unemployment rate in Poland for the 55-59 group was 5.08\% for men and $4.06 \%$ for women. It is worth noting that since 2000 this value has dropped significantly (not only in this age range) and is even lower than the EU average (7\% and $6.11 \%$ respectively). However, Sweden can boast the lowest unemployment rate in the 55-59 age group. The unemployment rate among Swedes aged 45+ is relatively low, though it increases with age. Although for Poland, Sweden and the EU over the last fifteen years the employment

\footnotetext{
${ }^{34}$ F. Stokowski, Demografia, Warszawa 2015, p. 55.
} 
rate has been growing and the decline in unemployment among people aged over 50 - especially in the case of Poland - can be seen, the withdrawal from the labour market of older generations is becoming a major socio-economic problem.

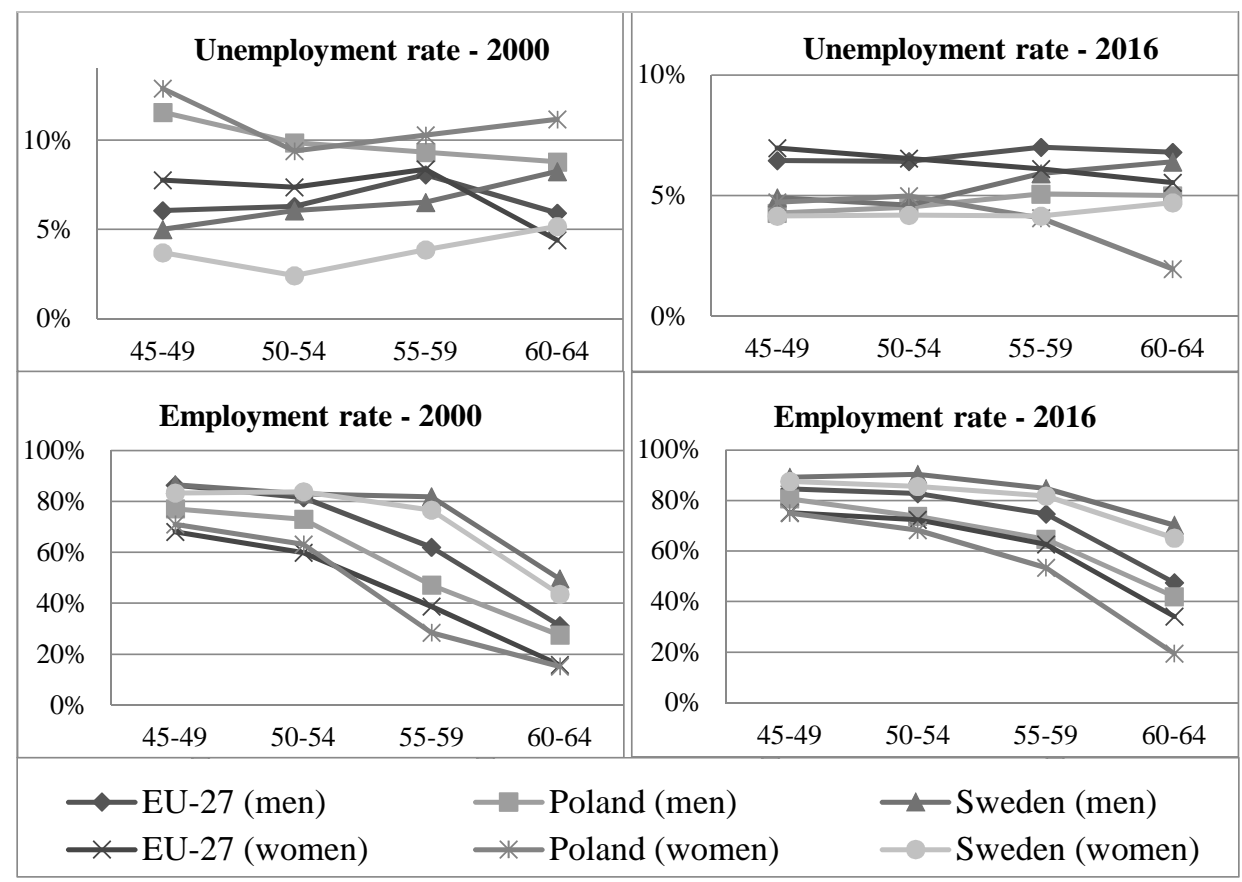

Figure 7. Demographic burden indicator in the EU, Poland and Sweden in the years 2000-2080

Source: own study based on Eurostat data: http://epp.eurostat.ec.europa.eu/portal/page/portal/population/data/database [lfsa_agan], [lfsa_ugan], [lfsa_egan], [demo_pjangroup].

One of the assumptions of the Europe 2020 strategy $^{35}$ is the increase of the percentage of employed persons aged 20-64 in the European Union to $75 \%$. These objectives are to be implemented, among others, by increasing economic activity of elderly people.

The economic activity rate in Poland for the population aged 55-64 remains at a low level and in 2016 it amounted to just over $48 \%$. It is a result lower by 10.9 percentage points than the average value of this indicator for the European Union. In comparison to Sweden - the country with the highest economic activity rate in the EU among the elderly - Poland rates much worse. Despite the increase in the economic activity rate recorded over the last 16 years in the 55-64 age group (from 32\% to 48\%), we are still far behind Sweden, for which the value of the discussed indicator amounted to $79.7 \%$ in 2016 . Even greater differences are visible in the 65-69 age group, in 2016 the difference between Poland and

${ }^{35}$ European Commission, Europe 2020. A European strategy for smart, sustainable and inclusive growth, Communication from the Commission, COM(2010) 2020, Brussels 2010, http://ec.europa.eu/eu2020/pdf/COMPLET\%20EN\%20BARROSO\%20\%20\%20007\%20-\%20Europe\%202020\%20-\%20EN\%20version.pdf (accessed: 18.06.2017). 

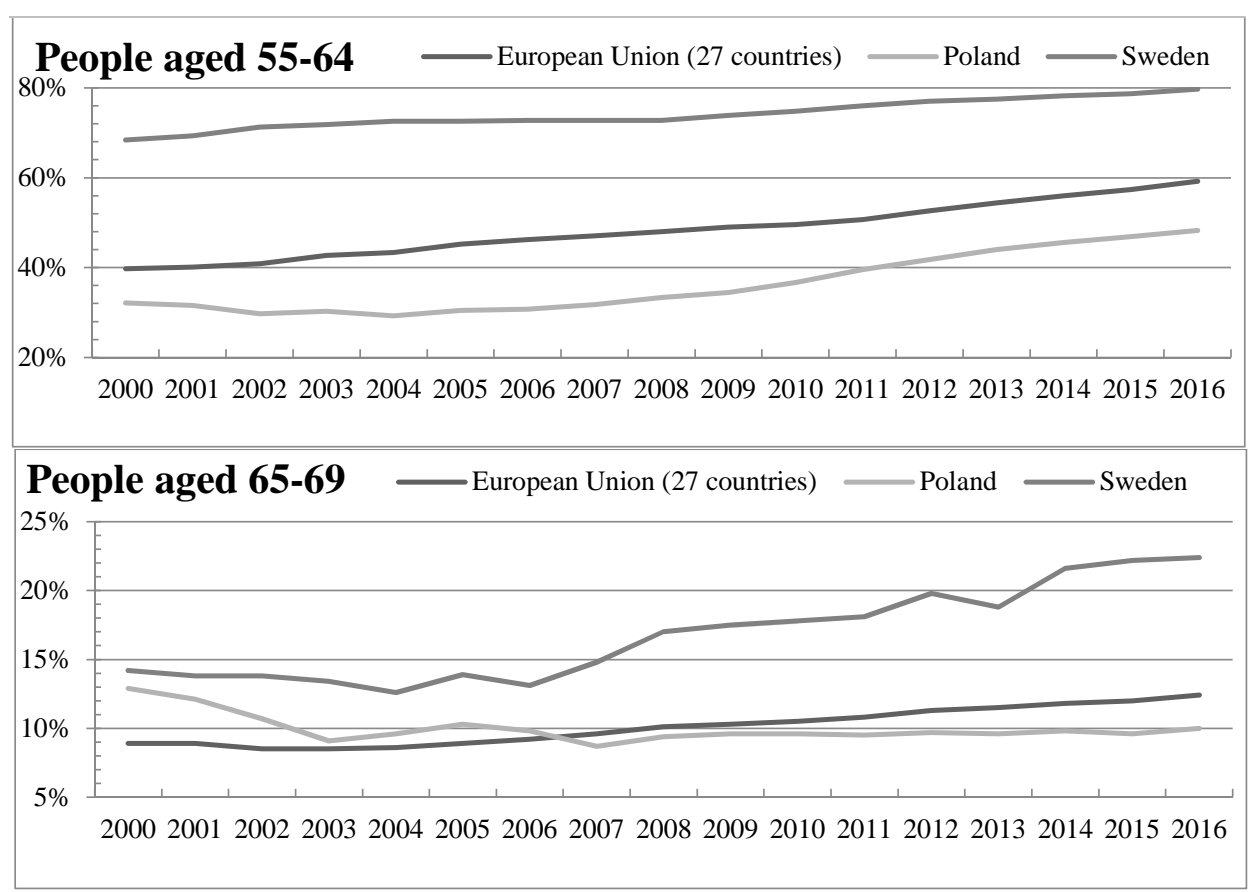

Figure 8. Demographic burden indicator in the EU, Poland and Sweden in the years 2000-2080

Source: own study based on Eurostat data:

http://epp.eurostat.ec.europa.eu/portal/page/portal/population/data/database [lfsa_argan].

Sweden amounted to as much as 12.4 percentage points (Poland $-10 \%$, Sweden $-22.4 \%$ ). The activity rate for people in this age group in the European Union in 2016 was at the level of $12.4 \%$, which is basically not much higher than in the case of Poland. It is also worth stressing that although economic activity of the elderly is lower for women, in Sweden these differences are not as significant as in Poland. In 2016, 82.6\% of men and 76.9\% of women in the 55-64 age group were economically active in Sweden, however, only 58.6\% of men and only $39 \%$ of women in Poland.

\section{Methods of professional activation of the elderly}

In the framework of the conducted policy, the state can use various tools to eliminate negative consequences of an ageing workforce. The basic instruments include:

- actions related to reforms of pension, social and tax systems,

- counteracting the discrimination and stereotypical attitude of employers towards the elderly,

- activities aimed at increasing the working capacity of elderly people and changing their passive attitude towards economic activity ${ }^{36}$.

\footnotetext{
${ }^{36}$ Z. Wiśniewski, Determinanty aktywności zawodowej ludzi starszych, Toruń 2009, p. 16.
} 
An important factor conducive to increasing economic activity is lifelong learning. Knowledge and skills acquired during school education are becoming obsolete. Over time, in the course of acquiring work experience and in the face of changes in the socio-economic sphere, they turn out to be insufficient. Maintaining one's position in the labour market requires flexibility and willingness to broaden one's knowledge and upgrade qualifications. The attitude towards lifelong learning is diversified among elderly employees mainly due to the level of education and the position held. In addition, elderly people tend to think that they are 'too old' to learn, although it is now known that it is not age that weakens our memory but the cessation of intellectual activity.

Sweden is an example of a country where people have a positive attitude towards lifelong learning. The participation of adult Poles in education or training is significantly lower than that of the Swedes. Poland, compared to the countries of the European Union, has one of the lowest rates of participation of adults in lifelong learning. On average, $4.9 \%$ of Europeans aged 55-74 participated in lifelong learning in 2016. The highest level of this indicator was achieved by Denmark $(19.3 \%)$ and the lowest level by Croatia $(0.2 \%)$. In contrast, for Poland in 2016, the percentage of people aged 55-74 participating in education or training was only $0.8 \%$ and increased since 2006 by only 0.3 percentage point. In the case of Sweden, as many as $17.8 \%$ of elderly people (aged between 55 and 74) participated in education or training, and this percentage increased since 2006 by 6.4 percentage points.

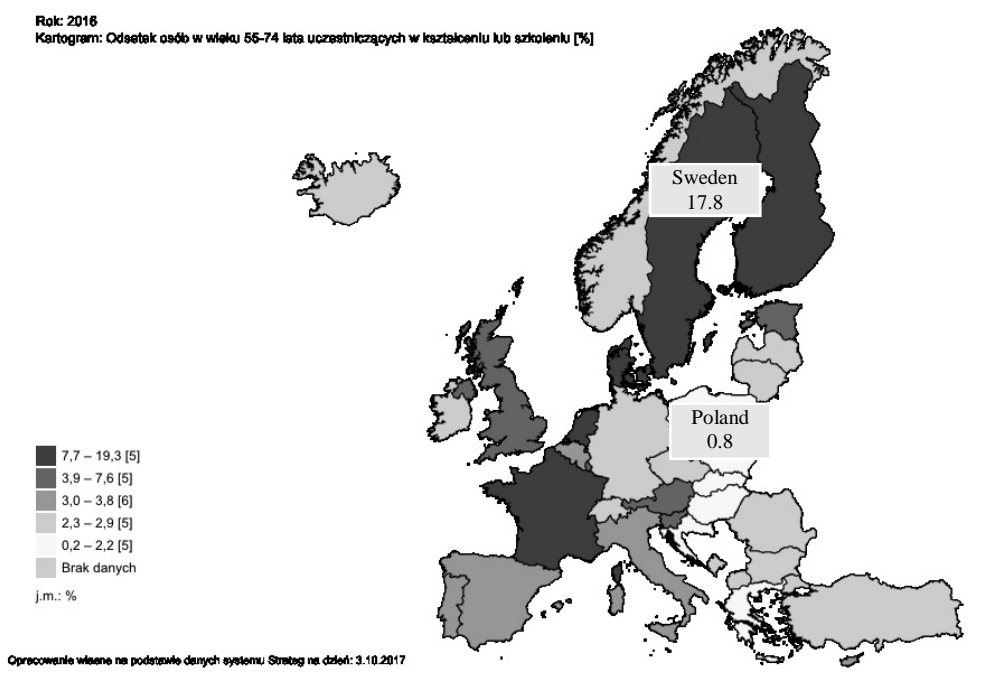

Figure 9. Percentage of people aged 55-74 participating in education or training in 2016 (\%)

Source: own elaboration based on data of the Central Statistical Office, Strateg system.

There are many ways to activate people over 50. Reforms aimed at limiting the scope and amount of benefits and instead rewarding people for a longer period of economic activity along with benefits aimed at increasing fertility seem to be the best solution. Limiting early retirement also requires reforms of the pension system, including changes consisting 
in increasing the retirement age $\mathrm{e}^{37}$. However, it is known that this proposal meets with social resistance among many employees, who, among others, put forward the argument about the right of elderly people to rest, pointing to their reduced performance or poor health ${ }^{38}$. That is why it is important to take actions tailored to the needs and capabilities of the elderly. It is possible to prolong professional activity while respecting the expectations of elderly employees, thus flexible forms of employment, i.e. part-time work, work at home or working time flexibility, need to be promoted. Currently, when knowledge and information play a dominant role in the world, the process of continuing education and improving qualifications, especially of elderly people, is becoming increasingly important. Enterprises that become knowledge-based organisations should use the concept of age management. This idea serves to promote the age diversity of the staff and prevents social exclusion, thus leading to the effective use of human resources ${ }^{39}$. It is also important to change the mentality of employers and younger employees, often convinced that a senior employee is a worse employee, while very often this is a person with extensive experience and strong motivation to work $^{40}$.

\section{CONCLUSIONS}

Currently, population ageing and low fertility are major threats to the labour market is. Due to the growing awareness of the issue, many EU countries consider the increase of economic activity of elderly people as the priority of labour market policy. The paper is an attempt to show the complexity of the process of population ageing along with the consequences of the phenomenon for the labour market. The examples of activities conducive to retaining elderly people in the labour market are also discussed.

The growing group of elderly people in the EU population, including Poland and Sweden, is an important and complex problem both in the social and economic context. The observed demographic changes give rise to the question of how the ageing of society will affect the functioning of the labour market. Effective use of labour resources requires first of all cultural change, as it is necessary to change the perception of the old age. One should begin to identify the age of 55+ with the image of an intellectually and professionally active person, bringing valuable experience to the workplace. Extending economic activity is inevitable nowadays. The full use of human resources will be possible when a well-functioning system of care for the elderly is created. Adapting to new demographic conditions is not easy, therefore it requires the consistent implementation of systemic changes with a broad spectrum of impact. The programme to counter negative effects of population ageing is a necessity. Delaying the implementation of remedial actions and abandoning the

${ }^{37}$ E. Kwiatkowski, B. Liberda, Determinanty rozwoju Polski. Rynek pracy i demografia, Warszawa 2015, p. 279.

38 J.T. Kowaleski, P. Szukalski (ed.), Pomyślne starzenie się w perspektywie nauk o pracy i polityce społecznej, Łódź 2008, p. 245.

39 Ibidem, p. 279.

${ }^{40}$ I. Kołodziejczyk-Olczak, Zarzadzanie pracownikami w dojrzałym wieku. Wyzwania i problemy, Łódź 2014, p. 20. 
creation of preventive measures may have disastrous consequences for the social structure in the coming decades ${ }^{41}$.

\section{REFERENCES}

1. Balcerowicz-Szkutnik M., Współczesne problemy demograficzne $w$ dobie globalizacji: aspekty pozytywne i negatywne. "Studia Ekonomiczne. Zeszyty Naukowe Wydziałowe Uniwersytetu Ekonomicznego w Katowicach”, 2011, nr 95.

2. Frąckiewicz L., Polska a Europa. Procesy demograficzne u progu XXI wieku. Proces starzenia się ludności Polski i jego spoteczne konsekwencje, Wydawnictwo Naukowe "Śląsk", Katowice 2002.

3. GUS, Podstawowe informacje o rozwoju demograficznym Polski do 2014 roku, information note, Warszawa 2015.

4. GUS, Zasady metodyczne statystyki rynku pracy i wynagrodzeń, Warszawa 2008.

5. Holzer J.Z., Demografia, wydanie VI zmienione, Polskie Wydawnictwo Ekonomiczne, Warszawa 2003.

6. Kijak R.J., Szarota Z., Starość. Między diagnozq a działaniem, Centrum Rozwoju Zasobów Ludzkich, Warszawa 2013.

7. Kołodziejczyk-Olczak I., Zarzadzanie pracownikami w dojrzałym wieku. Wyzwania i problemy, Wydawnictwo Uniwersytetu Łódzkiego, Łódź 2014.

8. Kowaleski J.T., Szukalski P. (ed.), Pomyślne starzenie się w perspektywie nauk o pracy i polityce społecznej, Zakład Demografii i Gerontologii Społecznej UŁ, Łódź 2008.

9. Krywult-Albańska M., Wałaszek M., Procesy reprodukcji ludności w Europie [in:] M. Balcerowicz-Szkutnik (ed.), Wspótczesne problemy demograficzne $w$ dobie globalizacji: aspekty pozytywne i negatywne. SE 95, Wydawnictwo Uniwersytetu Ekonomicznego w Katowicach, Katowice 2011.

10. Kryńska E., Szukalski P. (ed.), Rozwiąania sprzyjajace aktywnemu starzeniu się w wybranych krajach Unii Europejskiej. Raport końcowy, Wydawnictwo Uniwersytetu Łódzkiego, Łódź 2013.

11. Kurkiewicz J., (ed.), Procesy demograficzne i metody ich analizy, Wydawnictwo Uniwersytetu Ekonomicznego w Krakowie, Kraków 2010.

12. Kurkiewicz J., Struktura ludności według podstawowych cech demograficznych [in:] Jolanta Kurkiewicz (ed.), Procesy demograficzne $i$ metody ich analizy, Wydawnictwo Uniwersytetu Ekonomicznego, Kraków 2010.

13. Kwiatkowski E., Liberda B., Determinanty rozwoju Polski. Rynek pracy i demografia, Polskie Towarzystwo Ekonomiczne, Warszawa 2015.

14. OECD, MPiPS, Starzenie się i polityka zatrudnienia. Polska 2015. Lepsza praca wraz $z$ wiekiem, OECD-MPiPS, Warszawa 2015.

15. Rosset E., Proces starzenia się ludności. Studium demograficzne, Polskie Wydawnictwo Gospodarcze, Warszawa 1959.

16. Stokowski F., Demografia, Polskie Wydawnictwo Ekonomiczne, Warszawa 2015.

\footnotetext{
${ }^{41}$ R. Iwański, Wspótczynnik obcią̇enia demograficznego a rozwój społeczny, "Nowiny Lekarskie", nr 82(1), 2013, p. 46-50, http://www.nowinylekarskie.ump.edu.pl/uploads/2013/1/46_1_82_2013. pdf (accessed:10.10.2017).
} 
17. Szukalski P., Proces starzenia się ludności. Przyczyny, etapy, konsekwencje [in:] T. Grodzicki, J. Kocemba, A. Skalska (ed.), Geriatria z elementami gerontologii ogólnej. Podręcznik dla lekarzy i studentów, Wydawnictwo Via Medica, Gdańsk 2006, http://dspace.uni. lodz.pl/xmlui/bitstream/handle/11089/14269/geriatria.pdf?sequence=1\&isAllowed=y (accessed: 01.10.2017).

18. Szweda-Lewandowska Z., Raport krajowy - Szwecja. Rozdział VIII, Raport krajowy Szwecja [in:] E. Kryńska, P. Szukalski (ed.), Rozwiazania sprzyjające aktywnemu starzeniu się w wybranych krajach Unii Europejskiej, final report, Uniwersytet Łódzki, Łódź 2013.

19. Urbaniak B., Zatrudnienie i instytucje rynku pracy $w$ warunkach starzejacych się zasobów pracy - badania dla Polski, Wydawnictwo Uniwersytetu Łódzkiego, Łódź 2011.

20. Wiśniewski Z., Determinanty aktywności zawodowej ludzi starszych, Towarzystwo Naukowe Organizacji i Kierownictwa "DOM ORGANIZATORA”, Toruń 2009.

\section{DATABASES}

1. Eurostat, http://ec.europa.eu/eurostat/statistics-explained/index.php/Population_structure_ and_ageing

2. Eurostat, http://epp.eurostat.ec.europa.eu/portal/page/portal/population/data/database

3. [demo_pjan], [proj_15npms], [demo_pjangroup], [demo_gind], [demo_find], [lfsa_agan], [lfsa_ugan], [lfsa_egan], [demo_pjangroup], [lfsa_argan], [migr_pop3ctb].

4. GUS, http://demografia.stat.gov.pl/bazademografia/Tables.aspx.

5. Statistics Sweden, http://www.statistikdatabasen.scb.se/pxweb/en/ssd/START_BE_ BE0401.

\section{INTERNET SOURCES}

1. European Commission, Europe 2020. A European strategy for smart, sustainable and inclusive growth, Communication from the Commission, $\operatorname{COM}(2010)$ 2020, Brussels 2010, http://ec.europa.eu/eu2020/pdf/COMPLET\%20EN\%20BARROSO\%20\%20\%20007\%20\%20Europe\%202020\%20-\%20EN\%20version.pdf, (accessed: 18.06.2017).

2. Eurostat. 2017. Population structure and ageing, Statistics Explained. http://ec.europa.eu/ eurostat/statistics-explained/index.php/Population_structure_and_ageing (accessed: 18.08.2017).

3. Iwański R., 2013. Wspótczynnik obciążenia demograficznego a rozwój społeczny. "Nowiny Lekarskie" 82(1): 46-50, http://www.nowinylekarskie.ump.edu.pl/uploads/2013/1/46_1_82_ 2013.pdf (accessed:10.10.2017).

4. Komisja Europejska. 2010. EUROPA 2020. Strategia na rzecz inteligentnego i zrównoważonego rozwoju sprzyjajacego wtaczeniu społecznemu. KOM(2010) 2020, Bruksela. http:// ec.europa.eu/eu2020/pdf/1_PL_ACT_part1_v1.pdf (accessed:10.08.2017).

5. OECD, MIiR, 2013. Analiza wskaźnika zmian demograficznych $w$ wybranych regionach w Polski, Warszawa: MIiR, OECD - Local Economic and Employment Development (LEED), https://www.ewaluacja.gov.pl/media/42330/Raport_analiza_wskaznika_zmian_demograficznych.pdf (accessed: 12.08.2017).

6. SCB, 2016. Sveriges framtida befolkning 2016-2060, Statistiska Meddelanden, Stockholm: SCB. http://www.scb.se/Statistik/BE/BE0401/2016I60/BE0401_2016I60_SM_

BE18SM1601.pdf, (accessed: 18.06.2017). 
7. SCB, 2015. The future population of Sweden 2015-2060, Demographic reports, Stockholm: SCB. https://www.scb.se/Statistik/_Publikationer/BE0401_2015I60_BR_BE51BR1502.pdf, (accessed: 18.06.2017).

8. Urząd Statystyczny w Zielonej Górze, 2012. Spoteczno-gospodarcze uwarunkowania i konsekwencje wydtużania życia ludzkiego $w$ Europie Środkowej w czasach nowożytnych. Materiały z Zielonogórskich Spotkań z Demografią. Zielona Góra: Urząd Statystyczny w Zielonej Górze, https://stat.gov.pl/cps/rde/xbcr/gus/POZ_folder_konf_prezentacja.pdf (accessed: 19.09.2017).

9. Wróbel M., Modele dzietności względem zmiennych rynku pracy w miastach 100-tysięcznych $i$ większych w pierwszej dekadzie XXI wieku [in:] Polityka rodzinna w Polsce z perspektywy wybranych aspektów polityki społecznej i ekonomii Doświadczenia innych państw europejskich, A. Kubów, J. Szczepaniak-Sienniak (ed.), "Prace Naukowe Uniwersytetu Ekonomicznego we Wrocławiu" nr 364, 2014, http://www.dbc.wroc.pl/Content/27028/Wrobel_Modele_dzietnosci_wzgledem_zmiennych_rynku.pdf.

\section{PROCESY STARZENIA SIE LUDNOŚCI A AKTYWNOŚĆ ZAWODOWA OSÓB STARSZYCH W UNII EUROPEJSKIEJ NA PRZYKŁADZIE POLSKI I SZWECJI}

Z punktu widzenia rynku pracy malejąca liczba produktywnej części społeczeństwa ma niekorzystne konsekwencje dla rozwoju społeczno-gospodarczego. Starzenie się ludności jest to długofalowy proces znajdujący odzwierciedlenie w rosnącym udziale osób starszych w populacji, w połączeniu ze spadkiem udziału osób w wieku produkcyjnym w ogólnej liczbie ludności. Proces ten jest nieuniknioną konsekwencją przemian dwóch składowych ruchu naturalnego - rozrodczości i umieralności. Celem artykułu jest ocena sytuacji osób starszych na rynku pracy w obliczu zachodzących zmian demograficznych w UE, w tym w Polsce i Szwecji. Na podstawie danych empirycznych pokazane zostały różnice występujące pomiędzy Polską i Szwecją w sferze aktywizacji osób starszych, w podziale na kobiety i mężczyzn. W toku prowadzonej dyskusji ukazane zostało, że choć oba państwa borykają się z podobnymi przemianami w strukturze wiekowej ludności, to jednak skutki tychże problemów, głównie z punktu widzenia aktywności osób starszych na rynku pracy, są różne. Artykuł ma charakter faktograficzno-przeglądowy. W artykule omówione zostały podstawowe wskaźniki ekonomiczne wykorzystywane w ocenie procesów starzenia się ludności, w tym współczynnik obciążenia demograficznego. Analiza statystyczna została przeprowadzona w oparciu o dane publikowane statystyki publicznej pochodzące z baz Głównego Urzędu Statystycznego, Eurostatu oraz SCB (Statistics Sweden).

Słowa kluczowe: starzenie się ludności, kształcenie ustawiczne, Europa 2020, wskaźnik obciążenia demograficznego

DOI: 10.7862/rz.2018.hss.54

Przestano do redakcji: lipiec $2018 \mathrm{r}$.

Przyjęto do druku: wrzesień 2018 r. 
